\title{
The Heat of Combustion of Tobacco and Carbon Oxide Formation*
}

\author{
by \\ A.B. Norman, T.A. Perfetti, P.F. Perfetti and R.G. Hayworth \\ R. J. Reynolds Tobacco Company, Winston-Salem, NC 27102-1487, USA
}

\section{SUMMARY}

Recent studies demonstrated a relationship between mass burn rates of straight-grade cigarettes and heats of combustion of the tobacco materials. In the present work, relationships between measured heats of combustion and elemental composition of the tobacco materials were further analyzed. Heats of combustion measured in oxygen were directly correlated with the carbon and hydrogen content of the tobacco materials tested. Ash content of the materials was inversely related to the heats of combustion. The water insoluble residues from exhaustively extracted tobacco materials showed higher heats of combustion and higher carbon content than the non-extracted materials, confirming a direct relationship between carbon content and heat of combustion. A value for the heat of formation of tobacco was estimated (1175 $\mathrm{cal} / \mathrm{g}$ ) from the heat of combustion data and elemental analysis results. The estimated value for heat of formation of tobacco appears to be constant regardless of the material type. Heat values measured in air were uniformly lower than the combustion heats in oxygen, suggesting formation of $\mathrm{CO}$ and other reaction products.

Gases produced during bomb calorimetry experiments with five tobacco materials were analyzed for $\mathrm{CO}$ and $\mathrm{CO}_{2}$ content. When the materials were burned in oxygen, no $\mathrm{CO}$ was found in the gases produced. Measured heats of combustion matched estimates based on $\mathrm{CO}_{2}$ found in the gas and conversion of the sample hydrogen content to water. Materials burned in air produced $\mathrm{CO}_{2}(56 \%$ to $77 \%$ of the sample carbon content) and appreciable amounts of CO (7\% to $16 \%$ of the sample carbon content). Unburned residue containing carbon and hydrogen was found in the air combustion experiments. Estimated heat values based on amounts of $\mathrm{CO}$ and $\mathrm{CO}_{2}$ found in the gas and water formed from the hydrogen lost during combustion in air were higher than the measured values. These observations indicate formation of products containing hydrogen when the materials were burned in air. $\mathrm{CO}$ and $\mathrm{CO}_{2}$ formation during combustion in air were related to the composition of the tobacco materials. Materials with high carbon and low ash content showed evidence of higher $\mathrm{CO}_{2}$ formation. Amounts of unburned residue also varied with material composition. Thus, energy released during tobacco combustion in air is related to material-dependent formation of reaction products in addition to the carbon oxides and to the quantity of unburned material. [Beitr. Tabakforsch. Int. 19 (2001) 297-307]

\section{ZUSAMMENFASSUNG}

Neuere Untersuchungen haben gezeigt, dass es einen Zusammenhang zwischen der Abbrandrate von Cigaretten aus Tabaken eines Grades und der Verbrennungswärme des Tabakmaterials gibt. In der vorliegenden Untersuchung wurde der Zusammenhang zwischen der gemessenen Verbrennungswärme und der chemischen Zusammensetzung des Tabaks näher analysiert. Die in Sauerstoff gemessenen Verbrennungswärmen korrelierten direkt mit dem Kohlen- und Wasserstoffgehalt des untersuchten Tabakmaterials. Der Aschegehalt der Proben korrelierte invers mit der Verbrennungswärme. Die nicht in Wasser löslichen Rückstände von erschöpfend extrahiertem Tabakmaterial wiesen eine höhere Verbrennungswärme und einen höheren Kohlenstoffgehalt auf als nicht extrahiertes Material, wodurch ein direkter Zusammenhang zwischen dem Kohlenstoffgehalt und der Verbrennungswärme bestätigt wurde. Der Wert für die Bildungswärme des Tabaks wurde aus den Werten der Ver- 
brennungswärme und den Ergebnissen der Elementaranalyse geschätzt $(1175 \mathrm{cal} / \mathrm{g})$. Der geschätzte Wert für die Bildungswärme von Tabak scheint unabhängig von der Art des Materials konstant zu sein. Die in Luft gemessenen Verbrennungswärmen waren einheitlich niedriger als die in Sauerstoff gemessen Werte, was auf die Entstehung von $\mathrm{CO}$ und anderer Reaktionsprodukte hindeutet. Gase, die bei Experimenten mit einer kalorimetrischen Bombe bei fünf Tabaksorten freigesetzt wurden, wurden auf ihren $\mathrm{CO}$ - und $\mathrm{CO}_{2}$-Gehalt analysiert. Wurde das Tabakmaterial in Sauerstoff verbrannt, befand sich unter den produzierten Gasen kein CO. Die gemessenen Werte der Verbrennungswärme stimmten mit Schätzungen, die auf dem im Gas gefundenen $\mathrm{CO}_{2}$-Gehalt und der Umwandlung des Wasserstoffs der Probe in Wasser basierten, überein. Bei der Verbrennung des Tabakmaterials in Luft entstand $\mathrm{CO}_{2}(56 \%$ bis $77 \%$ des Kohlenstoffgehalts der Probe) und nennenswerte Mengen an CO (7\% bis 16\% des Kohlenstoffgehalts der Probe). Bei der Verbrennung in Luft fanden sich unverbrannte Rückstände, die Kohlenstoff und Wasserstoff enthielten. Die auf Basis des COund $\mathrm{CO}_{2}$-Gehalts im Gas und des gebildeten Wassers, welches aus dem Wasserstoff entstand, der während der Verbrennung in Luft verbraucht wurde, geschätzte Verbrennungswärme war höher als die gemessenen Werte. Diese Beobachtungen weisen darauf hin, dass bei der Verbrennung des Tabakmaterials in Luft Substanzen entstehen, die Wasserstoff enthalten. Es bestand ein Zusammenhang zwischen der Entstehung von $\mathrm{CO}$ und $\mathrm{CO}_{2}$ bei der Verbrennung in Luft und der Zusammensetzung des Tabakmaterials. Tabake mit einem hohen Kohlenstoffund einem niedrigen Aschegehalt wiesen eine höhere $\mathrm{CO}_{2}-$ Bildung auf. Die Mengen an unverbrannten Rückständen änderten sich ebenfalls mit der Zusammensetzung des Tabakmaterials. Somit gibt es einen Zusammenhang zwischen der während der Verbrennung des Tabaks in Luft freigesetzten Energie und der materialabhängigen Entstehung von Reaktionsprodukten, die neben den Kohlenstoffoxiden und der Menge an unverbranntem Material freigesetzt werden. [Beitr. Tabakforsch. Int. 19 (2001) 297-307]

\section{RESUME}

Des études récentes ont montré une relation entre la vitesse de combustion statique des cigarettes de grade unique et la chaleur de combustion du tabac. Dans cette étude la relation entre les chaleurs de combustion mesurées et la composition chimique du tabac a été analysée. La chaleur de combustion en présence d'oxygène est directement liée à la teneur en carbone et hydrogène du tabac testé. La teneur en cendres du tabac étudié est inversement liée à la chaleur de combustion. Les résidus insolubles dans l'eau extraits du tabac ont présenté des chaleurs de combustion et des teneurs en carbone plus élevées que les tabacs non extraits, confirmant une relation directe entre la teneur en carbone et la chaleur de combustion. La valeur de la chaleur formée à partir du tabac a été estimée $(1175 \mathrm{cal} / \mathrm{g})$ selon les données de la chaleur de combustion et des résultats de l'analyse élémentaire. La valeur estimée de la chaleur formée à partir du tabac semble être constante et ce quel que soit le type de tabac. Les valeurs de la chaleur de combustion en présence d'air est plus basse que les chaleurs de combustion en présence d'oxygène, suggérant la formation de $\mathrm{CO}$ et d'autres produits de réaction.

Les gaz produits par calorimétrie à bombe de cinq tabacs ont été analysés pour leur contenu en $\mathrm{CO}$ et $\mathrm{CO}_{2}$. Quand les matériaux sont brûlés en présence d'oxygène, on ne trouve pas de CO dans les gaz produits. Les chaleurs de combustion mesurées correspondaient aux estimations basées sur la teneur en $\mathrm{CO}_{2}$ du gaz et la conversion de l'hydrogène de l'échantillon en eau. Quand les tabacs sont brûlés en présence d'air, on trouve du $\mathrm{CO}_{2}(\mathrm{de} 56 \%$ à $77 \%$ de la teneur en carbone de l'échantillon) et des quantités non négligeables en CO (de 7\% à $16 \%$ de la teneur en carbone de l'échantillon). Les résidus non brûlés contenant du carbone et de l'hydrogène ont été trouvés dans les essais en présence d'air. Les valeurs estimées de la chaleur de combustion basées sur la teneur en $\mathrm{CO}$ et $\mathrm{CO}_{2}$ détectée dans le gaz et l'eau formée de l'hydrogène écarté pendant la combustion en présence d'air sont plus importantes que les valeurs mesurées. Ces observations indiquent la formation de produits contenant de l'hydrogène quand les tabacs sont brûlés en présence d'air. $\mathrm{La}$ formation de $\mathrm{CO}$ et $\mathrm{CO}_{2}$ au cours de la combustion en présence d'air est liée à la composition des tabacs. Les tabacs ayant une teneur élevée en carbone et une teneur faible en cendres présentent une formation plus importante de $\mathrm{CO}_{2}$. Les quantités des résidus non brûlés dépendent également de la composition du tabac. Ainsi, l'énergie dégagée au cours de la combustion du tabac en présence d'air est liée à la formation de produits de réaction qui dépendent du tabac en plus des oxydes de carbone et la quantité du matériau non brûlé. [Beitr. Tabakforsch. Int. 19 (2001) 297-307]

\section{INTRODUCTION}

Although a great deal of scientific work has been published on combustion products from burning cigarettes (1-3), and mechanisms for cigarette smolder (4-6), relatively little has been published on thermal properties of tobacco or cigarettes. Information on thermal properties of tobacco and cigarettes could be valuable for the design of unique products or for understanding the propensity of cigarettes to ignite upholstery, for example. In their summary of all work on cigarette and tobacco combustion prior to 1967, WYNDER and HOFFMANN (3) stated "[i]t seems surprising that relatively few efforts have been directed towards obtaining more information about the degree of combustion of tobacco". In 1981, MURAMATSU (4) critiqued his own and others' work on tobacco combustion. More recently, BAKER et al. in 1990 
Table 1.

Tobacco types tested for heats of combustion

\begin{tabular}{|c|c|}
\hline Type & Description \\
\hline FC A-D & $\begin{array}{l}\text { Contract grown flue-cured }(F C) \text { tobacco } \\
\text { separated by stalk position }(A=\text { bottom of } \\
\text { plant, } B=\text { mid-bottom of plant, } C=\text { upper } \\
\text { middle of plant, } D=\text { top of plant })\end{array}$ \\
\hline FC1 & Lower stalk group blend of flue-cured tobacco \\
\hline FC3 & Upper stalk group blend of flue-cured tobacco \\
\hline$B$ A-D & $\begin{array}{l}\text { Contract grown burley }(B) \text { tobacco separated } \\
\text { by stalk position }(A=\text { bottom of plant, } B=\text { mid- } \\
\text { bottom of plant, } C=\text { upper middle of plant, } \\
D=\text { top of plant })\end{array}$ \\
\hline B1 & Lower stalk group blend of burley tobacco \\
\hline B2 & Upper stalk group blend of burley tobacco \\
\hline FCBL & Blend of flue-cured and burley leaf \\
\hline O1 & Oriental leaf \\
\hline O5 & Oriental leaf \\
\hline FCBL/O5 & Blend of Oriental, flue-cured and burley leaf \\
\hline E1 & $\begin{array}{l}\mathrm{CO}_{2} \text { expanded }(\mathrm{E}) \text { flue-cured and burley cut } \\
\text { filler blend } 1\end{array}$ \\
\hline E2 & $\begin{array}{l}\mathrm{CO}_{2} \text { expanded flue-cured and burley cut filler } \\
\text { blend } 2\end{array}$ \\
\hline ESS & Expanded, shredded flue-cured stems \\
\hline CRES & Cut rolled expanded flue-cured stems \\
\hline RTS-A & Paper-type reconstituted tobacco sheet (RTS) \\
\hline RTS-B & $\begin{array}{l}\text { Heat treated paper-type reconstituted tobacco } \\
\text { sheet }\end{array}$ \\
\hline RTS-C & $\begin{array}{l}\text { Heat treated paper-type reconstituted tobacco } \\
\text { sheet with diammonium phosphate added to } \\
\text { the extract }\end{array}$ \\
\hline RTS-D & Paper-type reconstituted tobacco sheet \\
\hline RTS-X & $\begin{array}{l}\text { Experimental RTS, } 95 \% \text { scrap, } 5 \% \text { cellulose, } \\
\text { no tobacco extract }\end{array}$ \\
\hline
\end{tabular}

(5), and JENKINS et al. in 1996 (6) reviewed the state-ofthe-art of tobacco and cigarette combustion. The works cited were primarily studies that characterized how cigarettes burn. Few of the studies delved into the question of why tobacco types burn differently. Since then, NORMAN et al. (7) reported that the heats of combustion of different types of tobacco could be used to predict the burn rate of cigarettes. The present work was undertaken to develop an understanding of how other chemical properties of different tobaccos are related to their heats of combustion. While ideally we would like to know why different tobaccos burn differently, a sufficient base of information has not yet been developed to answer that question.

\section{Tobaccos}

A range of lamina and processed materials was tested. Descriptions of these materials are shown in Table 1.

\section{Preparation of water extracted tobacco samples}

Water-extracted materials (designated pulp) were prepared by placing $50 \mathrm{~g}$ of dried and ground tobacco into a stainless steel beaker with $800 \mathrm{~g}$ of $90^{\circ} \mathrm{C}$ deionized water. The mixture was stirred at $70 \mathrm{rpm}$ for $26 \mathrm{~min}$ and then cooled to room temperature by placing the beaker of aqueous suspension in an ice bath. The cooled aqueous suspension was then re-weighed and water was added to replace the moisture loss caused by sampling and evaporation. The final concentration of material was $0.125 \mathrm{~g}$ of tobacco suspension per gram of water. The suspension was filtered under low vacuum ( $<635 \mathrm{~mm} \mathrm{Hg}$, vacuum) with a Buchner funnel fitted with a fine mesh nylon screen. The filtrate was discarded and the pulp remaining on the filter was resuspended in $500 \mathrm{~mL}$ of water. This was repeated 4 times until the water filtrate was clear or only light tan in color. The dried, washed pulp was removed from the Buchner funnel, placed in a Petri dish and dried in an oven at $65^{\circ} \mathrm{C}$ for $3 \mathrm{~d}$. The dried pulp was ground to a fine powder with a mortar and pestle.

\section{Heat of combustion measurements}

Heat of combustion measurements were made with a Leco bomb calorimeter (Model AC300, Leco Corp., St. Joseph, Michigan). Tobacco was ground to a particle size that passed a 20 US mesh screen. The ground tobacco samples were tested at ambient moisture. Heat of combustion data were corrected to dry weight basis using moisture measurements made on the ground samples. Measurements were made with the bomb calorimeter filled with oxygen $(3034 \mathrm{kPa})$. Additional measurements were made with the bomb calorimeter filled with air (3034 kPa). Duplicate measurements were made for all samples at each test condition.

\section{Carbon monoxide and carbon dioxide determinations}

After selected samples were burned in the bomb calorimeter, some of the gas was vented into an evacuated Mylar ${ }^{\circledR}$ bag with a gas-tight fitting. Carbon dioxide $\left(\mathrm{CO}_{2}\right)$ and carbon monoxide $(\mathrm{CO})$ concentrations in the bag were measured with non-dispersive infrared spectrometers (Model 880, Rosemont Analytical, Beckman Industrial, Corp., La Habra, California) used for standard cigarette smoke analyses. Duplicate bags were prepared from the same calorimeter run for the samples burned in air. Concentrations of $\mathrm{CO}_{2}$ and $\mathrm{CO}$ found in the duplicate bags were almost identical. Weights of $\mathrm{CO}_{2}$ and $\mathrm{CO}$ generated from burning the samples were calculated from the measured gas concentrations ( $\%$ by volume), the gas pressure in the bomb $(3034 \mathrm{kPa})$ and the bomb volume $(309 \mathrm{~mL})$ using the ideal gas equation. For these calculations, we assumed ambient atmospheric pressure of 760 $\mathrm{mm} \mathrm{Hg}$ and temperature of $25^{\circ} \mathrm{C}$. We also assumed that the gas volume in the bomb increased after combustion by an amount equal to the total conversion of the sample 
carbon content to gases. At the conditions noted, initial gas volume was 9.2 L. The increase in volume assumed due to sample combustion ranged from 0.5 to $1 \mathrm{~L}$ depending on the sample weight and carbon content of the material. Additional experiments in air were completed for each sample in which the residue remaining after combustion was collected, weighed, and analyzed for carbon and hydrogen content.

\section{Tobacco analyses}

A gravimetric determination for the total inorganic composition of tobacco (ash) was used. A two-gram sample of dried and ground tobacco was ignited (ashed) for $3 \mathrm{~h}$ at $600^{\circ} \mathrm{C}$ employing a programmable furnace that slowly ramps the temperature to $600^{\circ} \mathrm{C}$, thus avoiding any pre-ashing steps.

Analyses of the total carbon, hydrogen and nitrogen content of tobacco samples were performed on a Perkin Elmer Series II CHNS/O Analyzer (Model 2400, Perkin Elmer Analytical Instruments, Norwalk, Connecticut) with combustion at $975^{\circ} \mathrm{C}$. Only carbon and hydrogen values are reported here.

\section{RESULTS AND DISCUSSION}

Heat of combustion data and selected elemental analysis results obtained for all tobacco materials tested (Table 1) are summarized in Table 2. As is evident from Table 2, heats of combustion measured in oxygen and in air varied with tobacco type. Carbon content of the materials was strongly correlated $(r=0.93)$ with heat of combustion measured in oxygen and moderately correlated $(r=0.71)$ with heat measured in air. Heat values measured in air were lower than those measured in oxygen and the values were correlated $(r=0.82)$. Ash content showed moderate inverse associations with both heat measures $(r=-0.71$ for oxygen; $r=-0.83$ for air). The association between ash and heat of combustion is probably a consequence of the relationship between carbon and ash content $(r=$ -0.62). Materials with higher carbon content had lower ash content and higher heat values. Comparison of the results for the water-extracted materials with those for the non-extracted controls confirms the influence of carbon content on measured heat values. The extracted materials showed lower ash, higher carbon content and higher heat values than the control materials. Table 3 shows the heat values and the elemental analyses averaged by material type, excluding the water-extracted materials. As can be seen in Table 3, the lamina materials and expanded tobacco showed higher heat values, higher carbon content and lower ash content than expanded stems and reconstituted tobacco sheet (RTS). This is the same trend noted for the comparison of results for the water-extracted and control materials.

Very few values for the total heat of combustion (i.e., in oxygen) of tobacco are available for comparison with the data in Tables 2 and 3. MURAMATSU (8) reported heats of combustion for three tobacco types with an average value of $3669 \mathrm{cal} / \mathrm{g}$. GUGAN (9) reported $3760 \mathrm{cal} / \mathrm{g}$ for an unspecified tobacco type. More recently, WAYMACK (10) reported $3550 \mathrm{cal} / \mathrm{g}$ as the average of a variety of blend components. Our average value of $4338 \mathrm{cal} / \mathrm{g}$ for lamina and expanded tobacco (Table 3 ) is higher than the previously reported results by 578 to $788 \mathrm{cal} / \mathrm{g}$. A definitive explanation for this discrepancy is unavailable. However, MURAMATSU (8) reported carbon content for the tobaccos for which heats of combustion were measured. The carbon content data were lower (average of 39\%) than our average of $42 \%$ for lamina and expanded tobacco (Table 3). This suggests MURAMATSU's heats of combustion could have differed from ours because of differences in the tobacco elemental composition.

The influence of tobacco carbon content on heats of combustion measured in oxygen was further examined by applying known relationships for calculating reaction heats. Assuming complete combustion as expected in calorimeter experiments employing excess oxygen, the reaction heat is the sum of the heats of formation of the combustion products $\left(\mathrm{CO}_{2}\right.$ and water) minus the sum of the heats of formation of the reactants. For tobacco, the heat of combustion is given by Equation [1].

$$
\Delta H=\left(n_{\mathrm{CO}_{2}} \Delta H_{\mathrm{CO}_{2}}+n_{\mathrm{H}_{2}} \Delta H_{\mathrm{H}_{2} \mathrm{O}}\right)-\Delta H_{\text {tob }}
$$

where

$$
\begin{aligned}
\Delta H & =\text { heat of combustion for tobacco, } \\
n_{\mathrm{CO}_{2}}= & \text { number of moles of } \mathrm{CO}_{2} \text { found per gram of } \\
& \text { tobacco, } \\
\Delta H_{\mathrm{CO}_{2}}= & \text { heat of formation of } \mathrm{CO}_{2}(94050 \mathrm{cal} / \mathrm{mol}), \\
n_{\mathrm{H}_{2}}= & \text { number of moles of diatomic hydrogen per } \\
& \text { gram of tobacco, } \\
\Delta H_{\mathrm{H}_{2} \mathrm{O}}= & \text { heat of formation of liquid water }(68300 \\
& \text { cal } / \text { mol }), \\
\Delta H_{\text {tob }}= & \text { heat of formation of tobacco. }
\end{aligned}
$$

To our knowledge the heat of formation of tobacco has not been reported in the literature. However, the form of Equation [1] indicates that a plot of the net heats from formation of $\mathrm{CO}_{2}$ and water (the value in parentheses) against measured heats of combustion should yield a line with a slope of 1 and intercept equal to the heat of formation of tobacco. This plot, shown in Figure 1, was constructed by converting the carbon and hydrogen content data from Table 2 to molar amounts (fractional carbon content data were divided by $12 \mathrm{~g} / \mathrm{mol}$ and fractional hydrogen data were divided by $2 \mathrm{~g} / \mathrm{mol}$ ) for application to Equation [1]. Regression analysis of the data in Figure 1 yielded a slope value of 0.99 and an intercept value of $1175 \mathrm{cal} / \mathrm{g}$. The excellent fit shown $\left(r^{2}\right.$ $=0.89$ ) suggests that this model adequately explains the variation in the heat of combustion data and that the apparent tobacco heat of formation value is constant regardless of tobacco type. Thus, we conclude that the 
Table 2.

Heat of combustion and elemental analysis results

\begin{tabular}{|c|c|c|c|c|c|c|}
\hline \multirow[b]{2}{*}{ Study } & \multirow[b]{2}{*}{ Material type } & \multicolumn{2}{|c|}{ Heat of combustion (cal/g) } & \multirow[b]{2}{*}{ Carbon (\%) } & \multirow[b]{2}{*}{ Hydrogen (\%) } & \multirow[b]{2}{*}{ Ash (\%) } \\
\hline & & $\mathrm{O}_{2}$ & Air & & & \\
\hline \multirow{6}{*}{$\begin{array}{l}\text { Water extracted } \\
\text { material }\end{array}$} & FCBL pulp & 4911 & 3640 & 44.86 & 7.43 & 6.57 \\
\hline & O5 pulp & 4843 & 2883 & 44.68 & 7.37 & 8.10 \\
\hline & E2 pulp & 4718 & 3416 & 44.25 & 7.35 & 6.91 \\
\hline & CRES pulp & 4006 & 3173 & 39.77 & 6.92 & 4.91 \\
\hline & RTS-D pulp & 4018 & 3336 & 39.33 & 6.72 & 7.82 \\
\hline & ESS pulp & 4196 & 3340 & 40.56 & 6.82 & 4.31 \\
\hline \multirow{6}{*}{$\begin{array}{l}\text { Controls for water } \\
\text { extracted material }\end{array}$} & FCBL & 4317 & 2629 & 40.62 & 6.66 & 13.57 \\
\hline & $\mathrm{O} 5$ & 4193 & 2121 & 39.23 & 6.67 & 13.13 \\
\hline & E2 & 4390 & 3199 & 40.98 & 6.36 & 13.47 \\
\hline & CRES & 3519 & 1900 & 34.42 & 5.67 & 18.37 \\
\hline & RTS-D & 3574 & 1893 & 34.16 & 5.63 & 18.84 \\
\hline & ESS & 3618 & 2113 & 35.85 & 5.30 & 19.63 \\
\hline \multirow{6}{*}{$\begin{array}{l}\text { Cigarette blend } \\
\text { components }\end{array}$} & RTS-D & 3534 & 1643 & 37.37 & 5.67 & 20.72 \\
\hline & ESS & 3553 & 2095 & 37.88 & 5.15 & 19.50 \\
\hline & CRES & 3429 & 1868 & 37.65 & 5.25 & 19.56 \\
\hline & E2 & 4403 & 3036 & 43.79 & 6.26 & 14.17 \\
\hline & FCBL/O5 & 4256 & 2163 & 42.87 & 6.16 & 14.83 \\
\hline & Cigarette Blend & 4035 & 2302 & 40.35 & 5.98 & 16.85 \\
\hline \multirow[t]{10}{*}{ Tobacco types } & $\mathrm{FC} 1$ & 4350 & 3089 & 42.97 & 6.33 & 14.18 \\
\hline & FC3 & 4719 & 3205 & 46.25 & 6.73 & 11.36 \\
\hline & B1 & 4087 & 2697 & 40.36 & 6.32 & 20.64 \\
\hline & B2 & 4226 & 2787 & 41.41 & 6.40 & 17.89 \\
\hline & 01 & 4427 & 2935 & 42.54 & 6.78 & 16.57 \\
\hline & CRES & 3504 & 2002 & 37.37 & 6.25 & 21.48 \\
\hline & $\mathrm{E} 1$ & 4348 & 3068 & 43.61 & 6.91 & 14.12 \\
\hline & RTS-A & 3622 & 2161 & 38.00 & 6.29 & 19.94 \\
\hline & RTS-B & 3646 & 2227 & 38.29 & 6.06 & 20.24 \\
\hline & RTS-C & 3569 & 2036 & 37.20 & 6.20 & 20.94 \\
\hline \multirow{4}{*}{$\begin{array}{l}\text { Flue-cured stalk } \\
\text { position }\end{array}$} & $\mathrm{FC} \mathrm{A}$ & & 2329 & 38.99 & 5.29 & 22.97 \\
\hline & FC B & & 2071 & 38.21 & 5.40 & 23.16 \\
\hline & FC C & & 3013 & 44.10 & 6.04 & 10.80 \\
\hline & FC D & & 3346 & 46.18 & 6.26 & 7.79 \\
\hline \multirow[t]{6}{*}{ Burley stalk position } & B A & & 1429 & 37.85 & 4.85 & 27.00 \\
\hline & B B & & 2044 & 42.21 & 5.84 & 19.09 \\
\hline & B C & & 2389 & 44.18 & 6.34 & 14.57 \\
\hline & B D & & 2424 & 44.12 & 6.53 & 12.96 \\
\hline & $\begin{array}{l}\text { Correlation with } \\
\text { carbon content }\end{array}$ & 0.93 & 0.71 & & 0.63 & -0.62 \\
\hline & $\begin{array}{l}\text { Correlation with } \\
\text { ash content }\end{array}$ & -0.71 & -0.83 & & -0.79 & \\
\hline
\end{tabular}

variation in heats of combustion by tobacco type shown in Table 2 and Table 3 is due to differences in carbon and hydrogen content of the materials.

As noted above, the heat values measured in air were lower than those measured in oxygen. The heat values in air and in oxygen were correlated as shown in Figure 2. The plot in Figure 2 indicates an average difference between heat values measured in air and in oxygen of $1739 \mathrm{cal} / \mathrm{g}$. Based on the analysis of heat values measured in oxygen described above, the lower heat values mea- 
Table 3.

Heat of combustion and elemental analysis results averaged by tobacco type ${ }^{a}$

\begin{tabular}{l|c|c|c|c|c}
\hline \multirow{2}{*}{ Material type } & \multicolumn{2}{|c|}{ Heat of combustion (cal/g) } & & \\
\cline { 2 - 3 } & $\mathrm{O}_{2}$ & Air & Carbon (\%) & Hydrogen (\%) & Ash (\%) \\
\hline Lamina and exp. tobaccos & 4338 & 2630 & 42.13 & 6.22 & 15.91 \\
$\quad$ Flue-cured & 4534 & 2842 & 42.78 & 6.01 & 15.04 \\
Burley & 4156 & 2295 & 41.69 & 6.05 & 18.69 \\
Oriental & 4310 & 2528 & 40.89 & 6.73 & 14.85 \\
Expanded & 4380 & 3101 & 42.79 & 6.51 & 13.92 \\
Stem and RTS & 3557 & 1994 & 36.82 & 5.75 & 19.92 \\
CRES & 3484 & 1923 & 36.48 & 5.72 & 19.80 \\
ESS & 3586 & 2104 & 36.87 & 5.23 & 19.57 \\
RTS & 3589 & 1992 & 37.00 & 5.97 & 20.14 \\
\hline
\end{tabular}

aData from Table 2 excluding water-extracted materials.

sured in air may be attributed to the formation of combustion products in addition to $\mathrm{CO}_{2}$ and water when tobacco is burned in air. The differences between heat values in oxygen and in air from Table 2 were not correlated with carbon content $(r=-0.1)$ but were weakly correlated with hydrogen content $(r=-0.4)$ and with ash content $(r=0.5)$. This suggests that hydrogen and ash content may influence the amounts of formation of additional reaction products when tobacco materials are burned in air.

A further study was conducted to confirm formation of the carbon oxides during combustion of tobacco in oxygen and in air and to investigate relationships between material composition and formation of combustion products for a selected number of samples. Data for the combustion heats (in oxygen) and gas concentrations of five different tobacco types (FC3, ESS, B2, RTS-C and RTS-X) are summarized in Table 4. Selected statistics averaged for the duplicate trials are shown in Table 5. As can be seen from Table 4, no CO was found in the gas taken from the bomb calorimeter. Nearly all the carbon in the test samples was converted to $\mathrm{CO}_{2}$ during combustion. On average (Table 5), molar amounts of carbon found as $\mathrm{CO}_{2}$ ranged from $90 \%$ to $97 \%$ of the carbon present in the material samples.

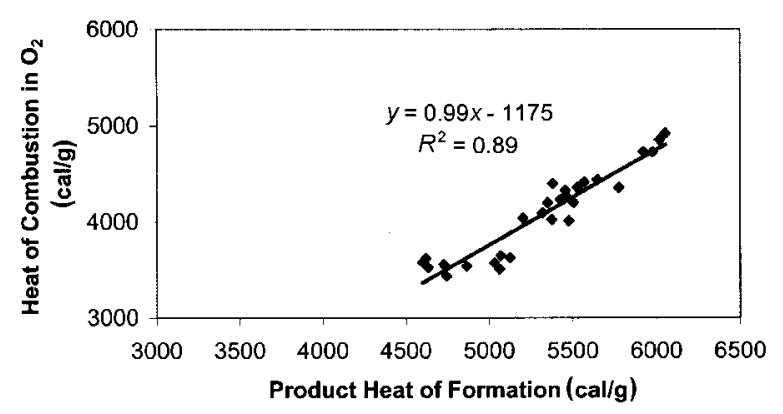

Figure 1.

Heat of formation of $\mathrm{CO}_{2}$ and water vs measured heat of combustion in oxygen
The measured amounts of $\mathrm{CO}_{2}$, the molar amounts of hydrogen $\left(\mathrm{as}_{2}\right)$ in the samples (Table 4$)$ and the heat of formation of tobacco $(1175 \mathrm{cal} / \mathrm{g})$ were used in Equation [1] to estimate heats of combustion. Heats of combustion estimated from Equation [1] closely matched the measured values (Tables 4 and 5), confirming that the heat values measured in oxygen arise from formation of $\mathrm{CO}_{2}$ and water. The incomplete recovery of carbon as $\mathrm{CO}_{2}$ suggests that small amounts of sample were not burned. Slightly higher heat estimates result from assuming 100\% conversion of the sample carbon content to $\mathrm{CO}_{2}$. Although we found no appreciable sample residue in the bomb calorimeter after combustion, the close match between measured and estimated heats using the $\mathrm{CO}_{2}$ amounts supports incomplete sample consumption indicated by the recovery data.

The results from the combustion heat and gas concentration experiments in air are summarized in Table 6. Selected statistics averaged for the duplicate trials are shown in Table 7. Appreciable amounts of $\mathrm{CO}$ were found in the gas from the bomb calorimeter but much larger amounts of $\mathrm{CO}_{2}$ were present (Table 6). Interestingly, the $\mathrm{CO}_{2} / \mathrm{CO}$ mole ratios found (Table 7) are in the same range as observed in sidestream cigarette smoke (8).

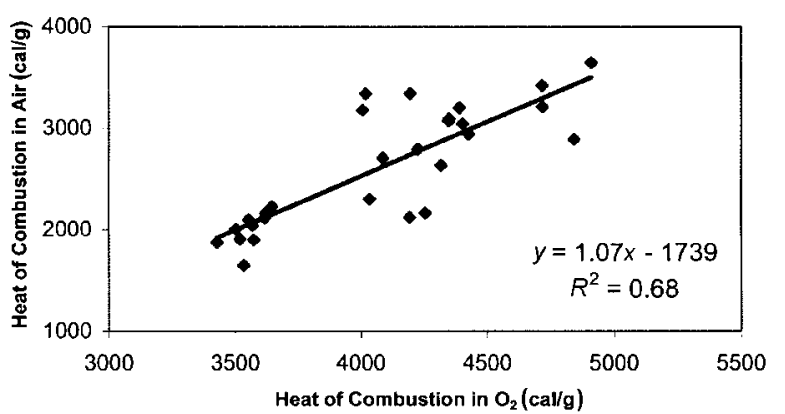

Figure 2.

Heat values measured in oxygen vs heat values measured in air 
Table 4.

Results of measurements made in oxygen

\begin{tabular}{|c|c|c|c|c|c|c|c|c|c|c|}
\hline Material sample & \multicolumn{2}{|c|}{ FC3 } & \multicolumn{2}{|c|}{ ESS } & \multicolumn{2}{|c|}{ B2 } & \multicolumn{2}{|c|}{ RTS-C } & \multicolumn{2}{|c|}{ RTS-X } \\
\hline Carbon (\%) & \multicolumn{2}{|c|}{46.70} & \multicolumn{2}{|c|}{37.84} & \multicolumn{2}{|c|}{41.94} & \multicolumn{2}{|c|}{38.15} & \multicolumn{2}{|c|}{42.52} \\
\hline Hydrogen (\%) & \multicolumn{2}{|c|}{6.08} & \multicolumn{2}{|c|}{4.49} & \multicolumn{2}{|c|}{5.20} & \multicolumn{2}{|c|}{4.93} & \multicolumn{2}{|c|}{5.62} \\
\hline \multirow[t]{2}{*}{ Ash (\%) } & \multicolumn{2}{|c|}{10.57} & \multicolumn{2}{|c|}{19.52} & \multicolumn{2}{|c|}{17.23} & \multicolumn{2}{|c|}{18.75} & \multicolumn{2}{|c|}{5.56} \\
\hline & Trial 1 & Trial 2 & Trial 1 & Trial 2 & Trial 1 & Trial 2 & Trial 1 & Trial 2 & Trial 1 & Trial 2 \\
\hline \multicolumn{11}{|l|}{ Calorimeter sample } \\
\hline Sample weight (g) & 1.0004 & 1.0007 & 0.6001 & 0.6166 & 1.0006 & 1.0005 & 1.0006 & 1.0001 & 0.8992 & 1.0007 \\
\hline Carbon $(\mathrm{mol})^{\mathrm{a}}$ & 0.039 & 0.039 & 0.019 & 0.019 & 0.035 & 0.035 & 0.032 & 0.032 & 0.032 & 0.035 \\
\hline Hydrogen $(\mathrm{mol})^{\mathrm{b}}$ & 0.030 & 0.030 & 0.013 & 0.014 & 0.026 & 0.026 & 0.025 & 0.025 & 0.025 & 0.028 \\
\hline Measured heat $(\mathrm{cal} / \mathrm{g})$ & 4569 & 4348 & 3332 & 3308 & 3827 & 3856 & 3313 & 3333 & 3539 & 3583 \\
\hline \multicolumn{11}{|l|}{ Gas from calorimeter } \\
\hline $\mathrm{CO}(\mathrm{mol})^{\mathrm{c}}$ & 0.000 & 0.000 & 0.000 & 0.000 & 0.000 & 0.000 & 0.000 & 0.000 & 0.000 & 0.000 \\
\hline $\mathrm{CO}_{2}(\mathrm{~mol})^{\mathrm{C}}$ & 0.039 & 0.036 & 0.018 & 0.017 & 0.032 & 0.032 & 0.029 & 0.028 & 0.029 & 0.032 \\
\hline Total $\mathrm{CO}_{x}(\mathrm{~mol})^{\mathrm{d}}$ & 0.039 & 0.037 & 0.018 & 0.017 & 0.032 & 0.032 & 0.029 & 0.028 & 0.029 & 0.032 \\
\hline $\mathrm{CO}_{2}\left(\% \text { of } \mathrm{CO}_{x}\right)^{\mathrm{e}}$ & 100 & 99 & 100 & 100 & 99 & 100 & 100 & 100 & 100 & 99 \\
\hline $\mathrm{CO}_{2}(\% \text { of } \mathrm{C} \text { in sample })^{\mathrm{f}}$ & 100 & 93 & 93 & 89 & 92 & 93 & 92 & 89 & 90 & 90 \\
\hline Estimated heat ${ }^{g}(\mathrm{cal} / \mathrm{g})$ & 4574 & 4311 & 3102 & 2996 & 3636 & 3644 & 3259 & 3183 & 3741 & 3740 \\
\hline
\end{tabular}

${ }^{a}$ Carbon content of the calorimeter sample as $\mathrm{C}$ calculated from material carbon \% multiplied by sample weight/1200.

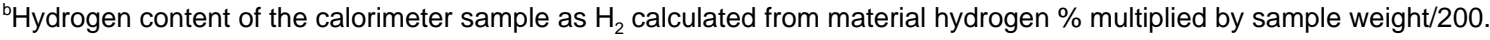

'Moles of carbon oxide found in the calorimeter after combustion of the sample weight indicated.

'Sum of molar amounts of $\mathrm{CO}$ and $\mathrm{CO}_{2}$.

eMolar amount $\mathrm{CO}_{2}$ found in gas/total carbon oxides found.

'Molar amount $\mathrm{CO}_{2}$ found in gas/molar amount of $\mathrm{C}$ in calorimeter sample.

${ }_{9}^{9}$ Heat estimated from $\mathrm{CO}_{2}$ found and formation of water from sample hydrogen content.

Table 5.

Measurements made in oxygen averaged by material type

\begin{tabular}{|c|c|c|c|c|c|}
\hline Material type & FC3 & ESS & B2 & RTS-C & RTS-X \\
\hline Measured heat $(\mathrm{cal} / \mathrm{g})$ & 4458 & 3320 & 3842 & 3323 & 3561 \\
\hline Estimated heat $^{\mathrm{a}}(\mathrm{cal} / \mathrm{g})$ & 4442 & 3049 & 3640 & 3221 & 3741 \\
\hline $\mathrm{CO}_{2}\left(\% \text { of } \mathrm{CO}_{x}\right)^{\mathrm{b}}$ & 99 & 100 & 100 & 100 & 100 \\
\hline $\mathrm{CO}_{2}(\% \text { of } \mathrm{C} \text { in sample })^{\mathrm{C}}$ & 97 & 91 & 92 & 91 & 90 \\
\hline
\end{tabular}

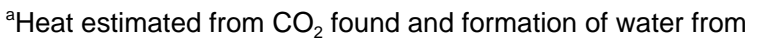
sample hydrogen content.

${ }^{b}$ Molar amount $\mathrm{CO}_{2}$ found in gas/total carbon oxides found.

'Molar amount $\mathrm{CO}_{2}$ found in gas/molar amount of $\mathrm{C}$ in calorimeter sample.

On average, the $\mathrm{CO}$ found represented $7 \%$ to $16 \%$ of the sample carbon content while the $\mathrm{CO}_{2}$ amounts were $56 \%$ to $77 \%$ of the sample carbon. Recovery of sample carbon as the oxides $\left(\mathrm{CO}_{x}\right)$ was lower than observed for the oxygen experiments and ranged from $63 \%$ to $88 \%$ (Table 7). These observations confirm the speculation that $\mathrm{CO}$ is formed in the air experiments and that the fraction of sample carbon converted to $\mathrm{CO}_{2}$ varies with material type. The incomplete recovery of sample carbon as the oxides suggests incomplete consumption of the sample and possibly formation of other products.
Estimates of the heat values in air $\left(H_{\text {est }}\right)$ were made with the measured amounts of $\mathrm{CO}$ and $\mathrm{CO}_{2}$ and the molar amounts of hydrogen $\left(\mathrm{as}_{2}\right)$ in the samples (Table 6) using

$$
\Delta H_{\text {est }}=n_{\mathrm{CO}_{2}} \Delta H_{\mathrm{CO}_{2}}+n_{\mathrm{CO}} \Delta H_{\mathrm{CO}}+n_{\mathrm{H}_{2}} \Delta H_{\mathrm{H}_{2} \mathrm{O}}-\Delta H_{\mathrm{tob}}[2]
$$

The symbols in Equation [2] have the same definitions as noted above. The additional term is the heat expected from $\mathrm{CO}$ formation, i.e., the number of moles of $\mathrm{CO}$ found per gram of tobacco $\left(n_{\mathrm{CO}}\right)$ multiplied by the heat of formation of $\mathrm{CO}\left(\Delta H_{\mathrm{CO}}, 26400 \mathrm{cal} / \mathrm{mol}\right)$. The estimates from Equation [2] were higher than the measured values (Tables 6, 7). Average estimate errors ranged from 346 to $897 \mathrm{cal} / \mathrm{g}$. A likely explanation for the high estimates is that the assumption that all of the hydrogen in the samples formed water is not correct. That is, if some of the hydrogen was not consumed during combustion, or was involved in formation of products other than water (with lower heats of formation), lower heats would result. Additional estimates of the heat values were made using Equation [2] with the assumption that the amounts of sample carbon not recovered as $\mathrm{CO}_{x}$ were equal to the amounts of hydrogen $\left(\right.$ as $\left.\mathrm{H}_{2}\right)$ not converted to water. That is, we assumed that equal proportions of carbon and diatomic hydrogen were unburned. These estimates were much closer to the measured values, suggesting some 
Table 6.

Results of measurements made in air

\begin{tabular}{|c|c|c|c|c|c|c|c|c|c|c|}
\hline Material sample & \multicolumn{2}{|c|}{ FC3 } & \multicolumn{2}{|c|}{ ESS } & \multicolumn{2}{|c|}{ B2 } & \multicolumn{2}{|c|}{ RTS-C } & \multicolumn{2}{|c|}{ RTS-X } \\
\hline Carbon (\%) & \multicolumn{2}{|c|}{46.70} & \multicolumn{2}{|c|}{37.84} & \multicolumn{2}{|c|}{41.94} & \multicolumn{2}{|c|}{38.15} & \multicolumn{2}{|c|}{42.52} \\
\hline Hydrogen (\%) & \multicolumn{2}{|c|}{6.08} & \multicolumn{2}{|c|}{4.49} & \multicolumn{2}{|c|}{5.20} & \multicolumn{2}{|c|}{4.93} & \multicolumn{2}{|c|}{5.62} \\
\hline \multirow[t]{2}{*}{ Ash (\%) } & \multicolumn{2}{|c|}{10.57} & \multicolumn{2}{|c|}{19.52} & \multicolumn{2}{|c|}{17.23} & \multicolumn{2}{|c|}{18.75} & \multicolumn{2}{|c|}{5.56} \\
\hline & Trial 1 & Trial 2 & Trial 1 & Trial 2 & Trial 1 & Trial 2 & Trial 1 & Trial 2 & Trial 1 & Trial 2 \\
\hline \multicolumn{11}{|l|}{ Calorimeter sample } \\
\hline Sample weight (g) & 1.0002 & 1.0004 & 0.6006 & 0.6003 & 1.0007 & 1.0009 & 1.0003 & 1.0005 & 1.0006 & 1.0010 \\
\hline Carbon $(\mathrm{mol})^{\mathrm{a}}$ & 0.039 & 0.039 & 0.019 & 0.019 & 0.035 & 0.035 & 0.032 & 0.032 & 0.035 & 0.035 \\
\hline Hydrogen $(\mathrm{mol})^{\mathrm{b}}$ & 0.030 & 0.030 & 0.013 & 0.013 & 0.026 & 0.026 & 0.025 & 0.025 & 0.028 & 0.028 \\
\hline Measured heat (cal/g) & 3245 & 3250 & 2022 & 2092 & 2501 & 2494 & 1533 & 1491 & 2431 & 2424 \\
\hline \multicolumn{11}{|l|}{ Gas from calorimeter } \\
\hline $\mathrm{CO}(\mathrm{mol})^{\mathrm{c}}$ & 0.005 & 0.004 & 0.003 & 0.003 & 0.004 & 0.004 & 0.002 & 0.002 & 0.003 & 0.003 \\
\hline $\mathrm{CO}_{2}(\mathrm{~mol})^{\mathrm{c}}$ & 0.030 & 0.030 & 0.012 & 0.012 & 0.023 & 0.023 & 0.018 & 0.018 & 0.026 & 0.027 \\
\hline Total $\mathrm{CO}_{x}(\mathrm{~mol})^{\mathrm{d}}$ & 0.035 & 0.034 & 0.015 & 0.015 & 0.027 & 0.028 & 0.020 & 0.020 & 0.030 & 0.030 \\
\hline $\mathrm{CO}\left(\% \text { of } \mathrm{CO}_{x}\right)^{\mathrm{e}}$ & 15 & 12 & 19 & 19 & 15 & 16 & 12 & 12 & 11 & 11 \\
\hline $\mathrm{CO}_{2}\left(\% \text { of } \mathrm{CO}_{x}\right)^{\mathrm{e}}$ & 85 & 88 & 81 & 81 & 85 & 84 & 88 & 88 & 89 & 89 \\
\hline $\mathrm{CO}(\% \text { of } \mathrm{C} \text { in sample })^{f}$ & 13 & 10 & 15 & 16 & 12 & 13 & 8 & 8 & 9 & 9 \\
\hline $\mathrm{CO}_{2}(\% \text { of } \mathrm{C} \text { in sample })^{\dagger}$ & 76 & 77 & 64 & 66 & 66 & 66 & 56 & 56 & 74 & 76 \\
\hline Estimated heat $^{g}(\mathrm{cal} / \mathrm{g})$ & 3819 & 3840 & 2369 & 2436 & 2886 & 2898 & 2249 & 2231 & 3295 & 3353 \\
\hline Estimated heat $^{\mathrm{h}}(\mathrm{cal} / \mathrm{g})$ & 3530 & 3510 & 1913 & 2034 & 2364 & 2397 & 1459 & 1432 & 2890 & 2989 \\
\hline
\end{tabular}

${ }^{a}$ Carbon content of the calorimeter sample as $\mathrm{C}$ calculated from material carbon \% multiplied by sample weight/1200.

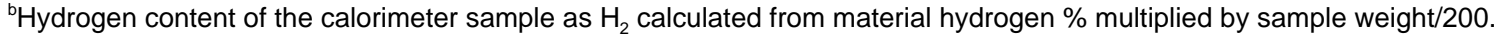

"Moles of carbon oxide found in the calorimeter after combustion of the sample weight indicated.

dSum of molar amounts of $\mathrm{CO}$ and $\mathrm{CO}_{2}$.

e Molar amount of carbon oxide found in gas/total carbon oxides found.

'Molar amount of carbon oxide found in gas/molar amount of $\mathrm{C}$ in calorimeter sample.

${ }^{9}$ Heat estimated from $\mathrm{CO}$ and $\mathrm{CO}_{2}$ found and formation of water from sample hydrogen content.

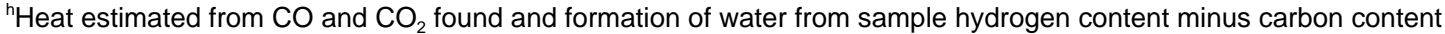
not found as $\mathrm{CO}_{x}$.

Table 7.

Measurements made in air averaged by material type

\begin{tabular}{|c|c|c|c|c|c|}
\hline Material type & FC3 & ESS & B2 & RTS-C & RTS-X \\
\hline Measured heat (cal/g) & 3248 & 2057 & 2497 & 1512 & 2428 \\
\hline Estimated heat $^{\mathrm{a}}(\mathrm{cal} / \mathrm{g})$ & 3830 & 2402 & 2892 & 2240 & 3324 \\
\hline Estimated heat ${ }^{b}(\mathrm{cal} / \mathrm{g})$ & 3520 & 1974 & 2381 & 1446 & 2940 \\
\hline $\mathrm{CO}\left(\% \text { of } \mathrm{CO}_{x}\right)^{\mathrm{c}}$ & 13 & 19 & 16 & 12 & 11 \\
\hline $\mathrm{CO}_{2}(\% \text { of } \mathrm{CO})^{\mathrm{c}}$ & 87 & 81 & 84 & 88 & 89 \\
\hline $\mathrm{CO}(\% \text { of } \mathrm{C} \text { in sample })^{\mathrm{d}}$ & 12 & 16 & 12 & 7 & 9 \\
\hline $\mathrm{CO}_{2}(\% \text { of } \mathrm{C} \text { in sample })^{\mathrm{d}}$ & 77 & 65 & 66 & 56 & 75 \\
\hline $\mathrm{CO}_{x}(\% \text { of } \mathrm{C} \text { in sample })^{\mathrm{e}}$ & 88 & 80 & 79 & 63 & 84 \\
\hline $\mathrm{CO}_{2} / \mathrm{CO}$ mole ratio & 6.6 & 4.2 & 5.4 & 7.5 & 8.0 \\
\hline
\end{tabular}

${ }^{\text {a }}$ Heat estimated from $\mathrm{CO}$ and $\mathrm{CO}_{2}$ found and formation of water from sample hydrogen content.

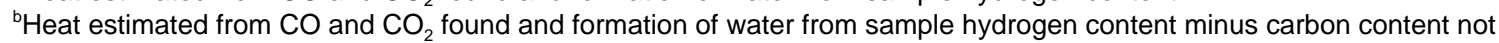
found as $\mathrm{CO}_{x}$.

'Molar amount of carbon oxide found in gas/total carbon oxides found.

${ }^{d}$ Molar amount of carbon oxide found in gas/molar amount of $\mathrm{C}$ in calorimeter sample.

${ }^{\text {e}}$ Recovery of sample carbon as oxides. 
Table 8.

Results of measurements made in air and residue analyses

\begin{tabular}{|c|c|c|c|c|c|}
\hline Material sample & FC3 & ESS & B2 & RTS-C & RTS-X \\
\hline Carbon (\%) & 46.70 & 37.84 & 41.94 & 38.15 & 42.52 \\
\hline Hydrogen (\%) & 6.08 & 4.49 & 5.20 & 4.93 & 5.62 \\
\hline Ash (\%) & 10.57 & 19.52 & 17.23 & 18.75 & 5.56 \\
\hline \multicolumn{6}{|l|}{ Residue sample } \\
\hline Carbon (\%) & 17.78 & 6.63 & 10.71 & 29.78 & 29.18 \\
\hline Hydrogen (\%) & 1.20 & 0.59 & 0.58 & 2.93 & 2.76 \\
\hline \multicolumn{6}{|l|}{ Calorimeter sample } \\
\hline Sample weight (g) & 1.0003 & 0.7005 & 1.0000 & 1.0003 & 1.0007 \\
\hline Carbon (mol) & 0.039 & 0.022 & 0.035 & 0.032 & 0.035 \\
\hline Hydrogen (mol) & 0.030 & 0.016 & 0.026 & 0.025 & 0.028 \\
\hline Measured heat (cal/g) & 2793 & 1831 & 2263 & 1292 & 2333 \\
\hline \multicolumn{6}{|l|}{ Residue after combustion } \\
\hline Sample weight (g) & 0.1417 & 0.1537 & 0.2194 & 0.4139 & 0.1259 \\
\hline Carbon $(\mathrm{mol})^{\mathrm{a}}$ & 0.002 & 0.001 & 0.002 & 0.010 & 0.003 \\
\hline Hydrogen $(\mathrm{mol})^{\mathrm{b}}$ & 0.001 & 0.000 & 0.001 & 0.006 & 0.002 \\
\hline \multicolumn{6}{|l|}{ Gas from calorimeter } \\
\hline $\mathrm{CO}$ (mol) & 0.006 & 0.004 & 0.006 & 0.002 & 0.005 \\
\hline $\mathrm{CO}_{2}(\mathrm{~mol})$ & 0.028 & 0.015 & 0.023 & 0.016 & 0.027 \\
\hline Total $\mathrm{CO}_{x}(\mathrm{~mol})$ & 0.034 & 0.019 & 0.029 & 0.018 & 0.031 \\
\hline $\mathrm{CO}\left(\%\right.$ of $\left.\mathrm{CO}_{x}\right)$ & 17 & 21 & 22 & 12 & 15 \\
\hline $\mathrm{CO}_{2}\left(\%\right.$ of $\left.\mathrm{CO}_{x}\right)$ & 83 & 79 & 78 & 88 & 85 \\
\hline CO (\% of C in sample) & 15 & 18 & 18 & 7 & 13 \\
\hline $\mathrm{CO}_{2}(\%$ of $\mathrm{C}$ in sample $)$ & 73 & 66 & 65 & 50 & 75 \\
\hline $\mathrm{CO}_{x}(\% \text { of } \mathrm{C} \text { lost from sample })^{\mathrm{C}}$ & 93 & 88 & 88 & 84 & 96 \\
\hline Estimated heat $^{d}(\mathrm{cal} / \mathrm{g})$ & 3661 & 2424 & 2854 & 1653 & 3241 \\
\hline Estimated heat ${ }^{e}(\mathrm{cal} / \mathrm{g})$ & 3341 & 1975 & 2372 & 1252 & 3085 \\
\hline
\end{tabular}

${ }^{a}$ Carbon content of the residue sample as $\mathrm{C}$ calculated from residue carbon $\%$ multiplied by sample weight/1200.

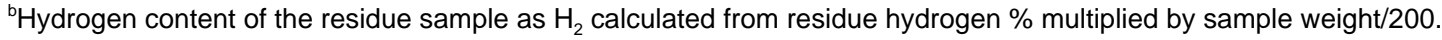

${ }^{\circ} \mathrm{Carbon}$ oxides found as the fraction of sample carbon content minus residue carbon content.

${ }^{d} \mathrm{Heat}$ estimated from $\mathrm{CO}$ and $\mathrm{CO}_{2}$ found and formation of water from sample hydrogen content minus residue hydrogen content.

${ }^{e}$ Heat estimated from $\mathrm{CO}$ and $\mathrm{CO}_{2}$ found and assuming formation of methane (Equation [3]).

validity for the unburned material assumption described. Since appreciable amounts of residue were found after burning the samples in air, we conducted additional experiments to quantify the residuals and to determine their gross elemental compositions. Given validity of the assumption regarding unburned residue discussed above, we expected to find carbon and hydrogen in the residues in equal proportions (i.e., C: $\mathrm{H}_{2}=1$ ) and sufficient carbon in the residue to explain the low carbon recovery as $\mathrm{CO}_{x}$. The results from these experiments are summarized in Table 8. Residue weights found varied from $13 \%$ to $41 \%$ of the sample weight burned in the calorimeter. The residue fractions were higher than the ash content of the samples, indicating some organic matter in the residues. Elemental analysis of the residues showed carbon content ranging from $6.6 \%$ to $29.8 \%$ and hydrogen content ranging from $0.58 \%$ to $2.93 \%$. These results yield an average $\mathrm{C}: \mathrm{H}_{2}$ mole ratio of 2.2 in the residues, which is clearly higher than the expected value. Also, the molar amounts of carbon found in the residues did not fully account for the low recovery of $\mathrm{CO}_{x}$. Recovery of sample carbon lost during combustion (i.e., sample carbon minus residue carbon) was in the same range as that found in the oxygen experiments (84\% to $96 \%$ ). Heat values were estimated from Equation [2] using the amounts of $\mathrm{CO}$ and $\mathrm{CO}_{2}$ found with the assumption that all of the hydrogen lost during combustion (sample $\mathrm{H}_{2}$ minus residue $\mathrm{H}_{2}$ ) formed water. These estimates (Table 8) were from 361 to $908 \mathrm{cal} / \mathrm{g}$ higher than the measured values. From these observations we concluded that some carbon and hydrogen must be involved in formation of products in addition to $\mathrm{CO}, \mathrm{CO}_{2}$ and water. Additional heat estimates were made assuming formation of methane from the carbon not found as $\mathrm{CO}_{x}$ or in the residue. The amounts of $\mathrm{H}_{2}$ required to form the appropriate quantities of methane were subtracted from the amounts of $\mathrm{H}_{2}$ lost from the samples to obtain the quantities of water formed. This is described mathematically in Equation [3]: 


\begin{tabular}{|c|c|c|c|c|}
\hline \multirow[b]{2}{*}{ Carbon oxide production statistic } & \multicolumn{4}{|c|}{ Material composition/correlation coefficient } \\
\hline & Carbon & Hydrogen & Ash & Carbon/Hydrogen \\
\hline $\mathrm{CO}_{2}(\% \text { of } \mathrm{C} \text { in sample })^{\mathrm{a}}$ & 0.85 & 0.79 & -0.83 & -0.36 \\
\hline $\mathrm{CO}(\% \text { of } \mathrm{C} \text { in sample })^{\mathrm{a}}$ & -0.06 & -0.33 & 0.33 & 0.84 \\
\hline $\mathrm{CO}_{x}(\% \text { of } \mathrm{C} \text { in sample })^{\mathrm{a}}$ & 0.74 & 0.59 & -0.63 & -0.05 \\
\hline $\mathrm{CO}_{2} / \mathrm{CO}$ mole ratio ${ }^{\mathrm{a}}$ & 0.30 & 0.57 & -0.66 & -0.96 \\
\hline $\mathrm{CO}_{x}(\% \text { of } \mathrm{C} \text { lost from sample })^{\mathrm{b}}$ & 0.70 & 0.73 & -0.96 & -0.52 \\
\hline
\end{tabular}

$$
\begin{aligned}
\Delta H_{\text {est }}= & n_{\mathrm{CO}_{2}} \Delta H_{\mathrm{CO}_{2}}+n_{\mathrm{CO}} \Delta H_{\mathrm{CO}}+n_{\mathrm{C}}^{\prime} \Delta H_{\mathrm{CH}_{4}} \\
& +n_{\mathrm{H}_{2}}^{\prime} \Delta H_{\mathrm{H}_{2} \mathrm{O}}-\Delta H_{\text {tob }}
\end{aligned}
$$

where

$$
\begin{aligned}
n_{\mathrm{C}}^{\prime}= & \text { sample carbon content }- \text { residue carbon } \\
& \text { content, } \\
n_{\mathrm{H}_{2}}^{\prime}= & \text { sample hydrogen content }- \text { residue hydrogen } \\
& \text { content } 2 n_{\mathrm{C}}^{\prime} \text { and } \\
\Delta H_{\mathrm{CH}_{4}}= & \begin{array}{l}
\text { heat of formation of methane } \\
\text { cal } / \mathrm{mol}) .
\end{array}
\end{aligned}
$$

The estimates made using Equation [3] (Table 8) were closer to the measured values than the previous estimates, suggesting some validity for the assumption that methane may be formed from the carbon not found as $\mathrm{CO}_{x}$ or in the unburned residue. Under our experimental conditions, several other products in addition to (or instead of) methane could be formed. The data analyses described are useful for indicating the potential for formation of other products and not their identities. Obviously, the amounts of products other than $\mathrm{CO}_{x}$ and water indicated were relatively small and subject to experimental error. However, it appears clear that the energy released from tobacco combustion in air is influenced by formation of products containing carbon and hydrogen as well as formation of CO.

Sample composition dependence of $\mathrm{CO}$ and $\mathrm{CO}_{2}$ formation was examined by calculating correlation coefficients for the associations between the elemental analysis results and the $\mathrm{CO}$ and $\mathrm{CO}_{2}$ data from Tables 6 and 8. The coefficients summarized in Table 9 demonstrate that $\mathrm{CO}_{2}$ production per mole of sample carbon was correlated with carbon, hydrogen and ash content of the samples. $\mathrm{CO}$ production per mole of sample carbon and $\mathrm{CO}_{2} / \mathrm{CO}$ mole ratio were correlated with the carbon/hydrogen ratio of the materials. Total carbon oxides $\left(\mathrm{CO}_{x}\right)$ produced per mole of carbon lost from the samples (i.e., the sample carbon content minus the residue carbon content) were correlated with sample carbon, hydrogen and ash content. These observations indicate that sample composition governs the relative amounts of $\mathrm{CO}$ and $\mathrm{CO}_{2}$ produced when the materials are burned in air.

\section{CONCLUSIONS}

Carbon and hydrogen content and heats of combustion data for a variety of tobacco materials were used to estimate the heat of formation of tobacco. The tobacco heat of formation $(1175 \mathrm{cal} / \mathrm{g})$ appears to be constant for the range of materials tested. The assumption that all of the carbon in the samples was converted to $\mathrm{CO}_{2}$ when the materials were burned in oxygen was confirmed with measurements of $\mathrm{CO}_{2}$ in the bomb calorimeter after sample combustion. Heats estimated from the $\mathrm{CO}_{2}$ formed, heat of formation of tobacco and the sample hydrogen content were close to the measured heats of combustion, suggesting that all of the hydrogen was converted to water in these experiments. Lower heat values were found when the tobacco materials were burned in air. $\mathrm{CO}_{2}$ and $\mathrm{CO}$ were found in the bomb calorimeter after combustion. Sample residuals after combustion contained carbon and hydrogen. Heat values estimated from amounts of $\mathrm{CO}$ and $\mathrm{CO}_{2}$ found and hydrogen lost during combustion were higher than the measured values. This suggests formation of reaction products containing carbon and hydrogen. Relative amounts of $\mathrm{CO}$ and $\mathrm{CO}_{2}$ produced when tobacco materials were burned in air appeared to depend on carbon, hydrogen and ash content of the materials.

\section{REFERENCES}

1. Green, C.R. and A. Rodgman: The Tobacco Chemists' Research Conference: A half century forum for advances in analytical methodology of tobacco and its products; Rec. Adv. Tob. Sci. 22 (1996) 131-304.

2. Rodgman, A.: FTC tar and nicotine in cigarette mainstream smoke: a retrospective; Rec. Adv. Tob. 
Sci. 23 (1997) 5-74.

3. Wynder, E.L. and D. Hoffmann: Tobacco and tobacco smoke, studies in experimental carcinogenesis; Academic Press, New York, 1967.

4. Muramatsu, M.: Studies on transfer phenomena during the natural combustion of cigarettes; Sci. Papers Cent. Res. Inst. Japan Tobacco and Salt Monop. Corp. 123 (1981) 9-77.

5. Baker, R.R. and D.P. Robinson: Tobacco combustion - The last ten years; Rec. Adv. Tob. Sci. 16 (1990) 3-72.

6. Jenkins, R.W. Jr. and D.D. McRae: Fifty years of research on cigarette smoke formation and delivery at the Tobacco Chemists' Research Conference; Rec. Adv. Tob. Sci. 22 (1996) 337-392.

7. Norman, A.B., R.G. Hayworth and T.A. Perfetti: Properties of tobacco related to cigarette burn rates; Tob. Sci. 43 (1999) 23-40.

8. Muramatsu, M., S. Umemura, and T. Okada: Consumption of oxygen and heat evolved during the natural smolder of a cigarette; Nippon Kagaku Kaishi 10 (1988) 1441-48.
9. Gugan, K.:Natural smolder in cigarettes; Combust. Flame 10 (1966) 161-164.

10. Waymack, B.E., D.S. Kellogg, D.D. McRae, and R.W. Dwyer: Watts in a cigarette: Thermophysical properties of smoldering cigarettes; Tob. Sci. 41 (1997) 74-81.

Address for correspondence

Alan B. Norman

Principal Scientist

Research and Development

R.J. Reynolds Tobacco Company

950 Reynolds Blvd.

Bowman Gray Technical Center

Winston-Salem, NC 27102

Phone: (336) 741-2117

Fax: (336) 741-0918 